\title{
ANTI-DISCRIMINATION POLICY AND THE ROMA: ASSESSING THE IMPACT OF EU ENLARGEMENT
}

\begin{abstract}
Melanie H Ram*
Summary: This article assesses the impact of the European Union's anti-discrimination policy on the Roma, with a focus on the 2000 Race Equality Directive and post-2004 enlargement developments. It explores the recent expansion of EU attention and action regarding discrimination and the Roma and then considers the direct and indirect results in terms of new national legislation and institutions in old and new Member States, Roma discrimination cases in national and international courts, public views on the Roma and discrimination, and changes in the actual situation of this minority. Overall, I find importantly a significant increase in interest, attention, and action by the EU regarding the Roma, gradual but important changes by governments of Member States, yet continuing discrimination, and ultimately little impact as yet on the lives of most Roma.
\end{abstract}

Minority rights, and later more specifically the improvement of the situation of their Roma (Gypsy) populations, was one of the many preconditions for countries in Central and Eastern Europe that hoped to join the European Union (EU). Before the 2004 and 2007 enlargements, ${ }^{1}$ the Roma across the EU also became protected under the EU's new anti-discrimination policies. This paper explores the impact of the EU's 2000 Race Equality Directive and related policies on the Roma, with a focus on post-enlargement developments. The Roma are a relatively poor and marginalised minority that has been subject to social exclusion and ethnic discrimination across Europe for centuries. Most believe that significant efforts to address their situation in Central and Eastern Europe began largely because it was necessary in order to attain EU membership. ${ }^{2}$ Shortly before enlargement, non-governmental organisa-

\footnotetext{
Melanie H Ram, Assistant Professor of Political Science at California State University, Fresno; 2225 East San Ramon, MS/MF19; Fresno, California 93740-8029, USA, and Research Associate at the Institute for European, Russian and Eurasian Studies, George Washington University, Washington, DC, USA; meram@csufresno.edu. An earlier version of this paper was presented at the Jean Monnet Seminar on Advanced Issues of European Law, 'European Law after the Big Bang Enlargement: Assessment and Perspectives' 5th session (Dubrovnik, 29 April - 6 May 2007). (c) Melanie H Ram 2007.

1 In May 2004, the Czech Republic, Estonia, Hungary, Latvia, Lithuania, Poland, Slovakia, Slovenia, Cyprus, and Malta joined the EU. In January 2007, Romania and Bulgaria joined.

2 Melanie H Ram, 'Democratization through European Integration: The Case of Minority Rights in the Czech Republic and Romania' (2003) 38 Studies in Comparative International Development 28-56.
} 
tions (NGOs) working on minority rights were concerned that the little progress achieved in their countries in order to gain EU membership might disappear after their countries joined the EU. ${ }^{3}$ Others hoped that discrimination might become less prevalent as a result of EU membership, in part due to increased interaction of people across borders in an enlarged EU, and in part because the EU might offer new opportunities to attract broader attention to their concerns. Still others thought EU enlargement would have little impact on the majority of Roma in new member countries. With ethnic discrimination now a new subject of EU law, this paper considers what this policy has generally achieved for the Roma across the EU. Specifically, has the disappearance of monitoring and conditionality once countries have gained EU membership brought about a deterioration in their situation? Or alternatively has accession to the EU further improved the rights and conditions of this minority, given them new opportunities to get their interests addressed and their discrimination redressed, and extended the attention to the Roma beyond the (former) candidate countries to all EU Member States? Now almost three years after the big 2004 expansion of the EU, it is possible to begin to make this assessment.

\section{The Situation of the Roma in Europe}

Believed to have migrated from India about one thousand years ago, the Roma today live in almost every European country, with a total population across Europe of approximately eight million including estimated populations of over half a million in at least five countries. ${ }^{4}$ With the recent EU enlargements to Central and Eastern Europe in 2004 and 2007, the Roma became the largest ethnic minority population in the EU. The problems of official discrimination against the Roma - including unequal access to housing, education, and employment - as well as racist attitudes towards them of the general population, and often extremely substandard living conditions have increasingly received attention since the mid-1990s in the run up to EU enlargement. As Roma activists emerged

\footnotetext{
3 This research was inspired in part by interviews by the author prior to enlargement with Roma and pro-Roma NGOs in the Czech Republic (December 2002) and Romania (June 2004).

4 These countries are Romania, Bulgaria, Hungary, Slovakia, and Spain. Romania has both the highest number (1-3 million) and percentage of Roma in its population. It should be noted that data on the number of Roma vary widely, in large part due to unreliable census figures. For various reasons, including discrimination, Roma often do not classify themselves as such. For example, less than half of the Roma surveyed in a recent UNDP survey in Bulgaria, the Czech Republic, Hungary, Romania, and Slovakia, said they had declared themselves to be Roma in their country's latest census. UNDP (Regional Bureau for Europe and the Commonwealth of Independent States), 'The Roma in Central and Eastern Europe: Avoiding the Dependency Trap' (Bratislava, 2002).
} 
and began to lobby on the issue, the EU began to criticise states that wished to join for the treatment of their Romani populations and compelled them to reform their legislation, establish new institutions, and make efforts to change social attitudes and root out discriminatory practices. ${ }^{5}$ While the Roma are more numerous in Central and Eastern Europe than in Western Europe, ${ }^{6}$ discrimination towards them has come to be recognised as a pan-European problem, as has now been catalogued in numerous reports by international organisations and NGOs. ${ }^{7}$ It should be understood that the problems confronted by the Roma are not only those of discrimination, but also of inferior socio-economic conditions. In particular, poverty and unemployment rates among Roma tend to be high and much higher than among non-Roma in the same countries. ${ }^{8} \mathrm{~A}$ recent survey in Romania found that over half of ethnic Roma still believe their standard of living was better under communism. ${ }^{9}$ While some local activists focus on discrimination as the key problem facing the Roma and others focus on poverty, it seems clear that the two are closely interconnected.

\section{EU Policy and Attention to Racial Discrimination and the Roma}

Thanks in part to continuing pressure from activists, EU action directed at - or directly affecting - the Roma, has been plentiful and appears to be growing. If one tracks the development of EU policy, attention, and

\footnotetext{
5 On the development of EU policy on the Roma as well as the role of Roma activists, see Melanie H Ram and Thomas T Holyoke, 'From the Sidelines to the Headlines: How the Roma Gained a "Voice" in European Politics', paper presented at the Annual Meeting of the American Political Science Association (Philadelphia, Pennsylvania, August 2003); Melanie H Ram, 'Lobbying the European Union from Afar: NGO Advocacy on Minority Rights in Candidate States', paper presented at the conference on Organised Civil Society and European Governance: Training, Recruitment and Practices of Interest Group Representatives in the European Union (Institut d'Etudes Politiques, Strasbourg, 21-23 June 2004).

6 The Roma in Central and Eastern Europe number about 6 million out of the total 8 million Roma in Europe.

7 For one of the early statements to this effect, see International Helsinki Federation for Human Rights, 'Human Rights in the OSCE Region: The Balkans, the Caucasus, Europe, Central Asia and North America' (2001) <www.ihf-hr.org> accessed 28 July 2001. See also Open Society Institute (EU Accession Monitoring Program), Monitoring the EU Accession Process: Minority Protection, Volume I: An Assessment of Selected Policies in Candidate States and Monitoring the EU Accession Process: Minority Protection, Volume II: Case Studies in Selected Member States (Open Society Institute, Budapest 2002).

8 For example, a 2000 survey found almost 80\% of Roma in Bulgaria and Romania and $40 \%$ in Hungary were living below the poverty line, all rates at least twice as high as poverty rates among non-Roma. See World Bank, 'Roma in an Expanding Europe' (World Bank, 2003) 3. A UNDP survey in 2002 compared poverty rates among Roma to those of Third World countries. See UNDP (n 4).

9 'Ethnic Roma are Humans Too, Aren't They' Divers Bulletin, 25 September 2006. The survey was conducted by Centre for Urban and Regional Sociology (CURS SA) for the National Democratic Institute.
} 
initiatives regarding the Roma, which began around 1997, it is possible to see a significant increase leading up to enlargement in 2004 and continuing thereafter. This in itself is a very important development for two reasons. First, as mentioned above, many individuals working to improve the situation of the Roma in candidate countries feared that the issue would drop from the agenda once their country joined the EU and they would no longer have the essential leverage provided by EU conditionality. For example, as a senior advisor in the Office on Roma Issues in Romania stated in a personal interview in mid-2004, 'Now we're getting close to EU integration, so the Roma issue is fading from focus of the EU, which means it is also fading from focus of the Romanian political class'. ${ }^{10}$ Second, the continued EU attention to the Roma is important because there is significant support among international Romani activists and others for the idea that the problems faced by the Roma should be, and perhaps can only be, resolved at the European level. ${ }^{11}$ As a new Member of the European Parliament, herself a Roma, expressed during a debate before a Resolution on the Roma in 2005, 'the only hope of the Romas lies in the European Union and European Parliament'. The European Commission also expressed support for this view in its statement before the Parliament's vote. As Vladimír Špidla, European Commissioner for employment, social affairs and equal opportunities stated, and numerous MEPs reiterated, 'the situation of the Roma is a European issue that calls for an EU solution'. ${ }^{12}$ Romania's Minister of European Accession Anca Boagiu echoed this point shortly before his country joined the EU, noting that there should be a European strategy to regulate the status of the Roma after accession. ${ }^{13}$ Thus, continued EU attention may be a critical factor in improving the situation of the Roma in Europe.

The anti-discrimination legislation adopted by the EU in 2000 may be considered the centrepiece of EU action so far, but was by no means the first or only attention directed by the EU towards the Roma. Nor was it specifically addressed to the Roma - it included several grounds of discrimination besides ethnicity, and targeted other ethnic groups in addition to the Roma (most notably, migrant populations). Nonetheless, it is clear that a number of important developments at the EU level affecting the Roma have followed this new policy. It also provided a new weapon for Roma rights activists to further their agenda. As the European Roma

10 Interview with the Office on Roma Issues, Government of Romania (June 2004).

11 Local activists do not all agree on this point.

12 European Parliament, 'The Roma in the European Union' (Debate, 27 April 2005) <http://www.europarl.eu.int/omk/sipade3?L=EN\&PUBREF=-//EP//TEXT+CRE+20050 427+ITEMS+DOC+XML+VO//EN\&NAV=S\&MODE=XML\&LSTDOC=N\&LEVEL=3\&SAME_ LEVEL $=1>$ accessed 1 November 2006.

13 'EU Focuses on Ethnic Roma Issue’ Divers Bulletin, 18 September 2006. 
Rights Centre (ERRC) has stated, for example, it 'recognised early the value for the Roma rights agenda' of ensuring that governments adopt and fully implement comprehensive anti-discrimination legislation in accordance with EU standards. ${ }^{14}$

For prospective EU Member States, EU obligations with regard to the situation of the Roma stemmed in part from the Copenhagen Criteria in 1993, requiring any new EU members to have domestic institutions 'guaranteeing democracy, the rule of law, human rights, and respect for and protection of minorities'. All EU members are also expected to respect fundamental rights as guaranteed by the European Convention for the Protection of Human Rights and Fundamental Freedoms, according to the Treaty on European Union under Article 6. This statement was further clarified and strengthened by provisions of the Amsterdam Treaty in 1997, adding that 'the Union is founded on the principles of liberty, democracy, respect for human rights and fundamental freedoms, and the rule of law, principles which are common to the Member States'. The Amsterdam Treaty also extended the powers of the European Court of Justice to this article and made it possible to suspend some rights of Member States that violate these principles.

Beyond human rights generally, the Amsterdam Treaty also added new provisions specifically to combat discrimination, including ethnic discrimination. According to Article 13, the Council "may take appropriate action to combat discrimination based on sex, racial or ethnic origin, religion or belief, disability, age or sexual orientation'. According to Commissioner Špidla, this new provision of the Amsterdam Treaty 'represented a quantum leap forward in the fight against discrimination' as it gave the EU powers to combat discrimination on various new grounds and made it clear to all that equality and non-discrimination are "part of the bedrock of fundamental rights on which the EU is based'. ${ }^{15} \mathrm{~A}$ prohibition against ethnic discrimination is also included in the EU's new Charter of Fundamental Rights adopted in December 2000. ${ }^{16}$ While the Charter is not as yet incorporated into a binding EU treaty, EU institutions have committed themselves to respecting it.

14 ERRC, 'Implementing Comprehensive Anti-Discrimination Law' <http://www.errc.org/ About_index.php> accessed 31 October 2006.

15 European Commission, 'Equality and non-discrimination - Annual report 2006' 32 <http://ec.europa.eu/employment_social/eyeq/uploaded_files/documents/spidla_ en.pdf> accessed 23 March 2007.

16 Article 21 of the Charter of Fundamental Rights (Non-discrimination) states as follows: 'Any discrimination based on any ground such as sex, race, colour, ethnic or social origin, genetic features, language, religion or belief, political or any other opinion, membership of a national minority, property, birth, disability, age or sexual orientation shall be prohibited.' <http://ec.europa.eu/justice_home/unit/charte/index_en.html> accessed 23 March 2007. 
Two European Community Directives on discrimination and an Action Program followed the provisions of the Amsterdam Treaty in 2000 (stemming from Article 13). The first was a Racial Equality Directive (Directive 2000/43/EC of 29 June 2000), which prohibits discrimination on grounds of race or ethnic origin in employment, education, social security, healthcare, and access to goods and services, including housing. The second was an Employment Framework Directive (Directive 2000/78/EC of 27 November 2000), which bars discrimination in employment on the grounds of religion and belief, disability, age, and sexual orientation. ${ }^{17}$ These Directives complemented already existing EC law on discrimination on the basis of gender.

Among the important provisions of the Race Directive is a requirement (Art 13) for EU Member States to designate a body to promote equal treatment of all races; the work of this body should include providing assistance to victims of discrimination, conducting independent surveys, publishing reports, and making recommendations. Judicial and/or administrative procedures must also be available to ensure the Directive is enforced (Art 7). In an alleged case of discrimination, there is also a shift in the burden of proof in that once the victim has established the facts suggesting discrimination, the respondent must prove that the principle of equal treatment has not been violated (Art 8). Sanctions for violating the national legislation adopted under the Directive must be 'effective, proportionate and dissuasive' and may include payment to the victim (Art 15). Finally, to achieve 'full equality in practice,' the Directive also allows 'positive action,' which is defined as 'measures to prevent or compensate for disadvantages linked to racial or ethnic origin' (Art 5).

Recognising that discrimination could not be eliminated through legislation alone, the EU also established a six-year (2001-2006) European Community Action Programme to raise awareness and understanding of the issue, help inform people of their rights and obligations, and otherwise support the fight against discrimination. The Roma were specifically identified as a priority for funding to address their difficulties in access to education and employment. Organisations concerned with the Roma were encouraged to apply for funding for projects, and several Roma projects are being supported under the program. ${ }^{18}$ Also under the Community Action Program, the Commission intended to support a European-level NGO specifically to defend Roma rights. While the Action Program typically funded one network per ground of discrimination, the

17 Only the first Directive will be addressed here, as the latter Directive does not include racial discrimination.

18 European Commission, 'Equality and non-discrimination - Annual report 2005' (April 2005) $31<$ http://ec.europa.eu/employment_social/fundamental_rights/pdf/pubst/poldoc/annualrep05_en.pdf> accessed 23 March 2007. 
Commission felt it necessary in the case of the Roma to establish a network specifically supporting their needs and interests. ${ }^{19}$

In terms of the attention of various EU institutions to racial discrimination, and to the Roma in particular, one could note numerous other developments since 2000. For example, the European Commission established a EU Network of Independent Experts in Fundamental Rights in September 2002. Among other tasks, it produces an annual 'Report on the Situation of Fundamental Rights in the European Union and its Member States,' which includes discrimination issues and the Roma. In 2003, the European Commission also funded a study on 'The Situation of Roma in an Enlarged European Union' written by a consortium of three organisations, including the European Roma Rights Centre, and sponsored a large conference in Brussels of the same title just prior to enlargement in 2004.

Just after the 2004 enlargement, the EU took additional actions to further the anti-discrimination agenda and improve the situation of the Roma. First, the European Commission adopted a Green Paper on 'Equality and non-discrimination in an enlarged EU' in May 2004 with the intention of assessing progress on anti-discrimination since the adoption of the Directives and considering post-enlargement challenges and policy priorities. ${ }^{20}$ The Roma were specifically identified by the Commission as one of the groups that should be addressed in the open consultation on the Green Paper (held June-August 2004). According to a press release on the Green Paper, enlargement brings new opportunities for cooperation regarding disadvantaged groups, including the Roma, 'often a victim of discriminatory practices'. ${ }^{21}$ Also in 2004, the European Commission established a new Group of Commissioners for Fundamental Rights, Anti-Discrimination and Equal Opportunities chaired by the Commission President in order 'to drive forward the policy agenda' and ensure coordination among various initiatives. According to a Commission report, the establishment of this group was an indication of 'the high priority accorded by the Commission to policy in this area'. ${ }^{22}$

19 European Commission (Community Action Programme to Combat Discrimination 20012006), 'Call for Proposals VP/2005/013 for the support towards the operating costs of a European level non-governmental organisation representing and defending the rights of Roma people' 2-3 <http://ec.europa.eu/employment_social/fundamental_rights/callspt/ calls05_en.htm> accessed 18 July 2005.

20 European Commission, 'Equality and non-discrimination in an enlarged European Union' (Green Paper, May 2004) <http://ec.europa.eu/employment_social/fundamental_ rights/pdf/pubst/grpap04_en.pdf> accessed 23 March 2007.

21 European Commission, 'Commission canvasses opinion on future direction of anti-discrimination policy' IP (2004) 709, 3 June 2004 <http://ec.europa.eu/employment_social/ fundamental_rights/pdf/green/greenpappr709_en.pdf> accessed 23 March 2007.

22 European Commission, 'Equality and non-discrimination - Annual report 2005' (n 18)

5 . 
Again in the year of enlargement, the Commission (DG, Employment and Social Affairs) created a European Network of Independent Legal Experts in the non-discrimination field, replacing three separate networks of independent experts on different grounds of discrimination that had been created by the Commission shortly after the anti-discrimination Directives were adopted. The experts are tasked with providing the Commission with independent information and advice to help ensure that the new anti-discrimination obligations (specifically the two new Directives) are effectively implemented. ${ }^{23}$ This has included producing a biannual European Anti-Discrimination Law Review, the first of which appeared in April 2005, providing an overview and assessment of new policies in every Member State to implement the EU's Directives. The Roma have been a prominent issue in their reports.

The European Parliament has been no less active in furthering the agenda of anti-discrimination and promoting attention to the Roma in particular. Its 2000 Annual Report on Human Rights, for example, noted widespread discrimination against the Roma and considered it 'vital' that improving their situation in the applicant countries is made an important part of the accession strategy. ${ }^{24}$ New action can be seen post-enlargement, facilitated in part by the inclusion in the new Parliament in 2004 of the first two Roma members, both from Hungary. For example, European Parliament members formed an Antiracism and Diversity Intergroup in October 2004 to promote respect for diversity and equal treatment, regardless of ethnic origin; discrimination faced by the Roma is one of its main priorities. ${ }^{25}$ One MEP from Hungary also created a 'Roma Forum' in order to lobby for the Roma and provide a link between national governments and the European Parliament on Roma issues. The European People's Party also formed a Working Group on the inclusion of the Roma. ${ }^{26}$ Importantly, in April 2005 the European Parliament adopted a 'Resolution on the Situation of Roma in the European Union'. The resolution emphasised 'the importance of urgently eliminating continuing and violent trends of racism and racial discrimination against Roma,' recounted numerous disadvantages faced by the Roma (including poverty and social

\footnotetext{
${ }^{23}$ Odile Quintin, 'Preface' (2005) 1 European Anti-Discrimination Law Review 7; Jan Niessen and Piet Leunis, 'An Introduction to the European Network of Legal Experts in the NonDiscrimination Field' (2005) 1 European Anti-Discrimination Law Review 11.

24 European Parliament, '1999 Annual Report on International Human Rights and European Union Human Rights Policy’ A5-0060/2000 final 23.

25 Anti-Racism Diversity Intergroup <http://www.enar-eu.org/anti-racism-diversity-intergroup/about.html > accessed 24 March 2007; Office for National and Ethnic Minorities (Budapest, Hungary), 'Selection of news on national and ethnic minorities in Hungary, Oct. 2004 - Jan. 2005' <http://www.fuen.org/pdfs/20050125HGOV_newsletter.pdf> accessed 24 March 2007.

26 Office for National and Ethnic Minorities (n 25).
} 
exclusion; discrimination in health care and social security, education, and other areas; substandard living conditions; unacceptably high unemployment rates; and often systemic discrimination by police forces), and called on various EU bodies, EU Member States, and candidate countries to take specific actions to address these concerns. ${ }^{27}$

After the Parliament's resolution and following consultations on the Green Paper, in mid-2005 the European Commission adopted a framework strategy to support the non-discrimination and equal opportunities agenda. Based on the over 1500 responses received on the Green Paper from various stakeholders, three main priorities were identified for future EU funding: information and awareness-raising, analysis and monitoring of the impact of anti-discrimination legislation, and networking between groups involved in the fight against discrimination. ${ }^{28}$ Funding would be provided through the Community action programme to combat discrimination until 2007, after which the new PROGRESS programme would take over supporting EU activities in anti-discrimination from 2007 to 2013. The Roma were singled out in the framework strategy in the context of the social and labour market integration of ethnic minorities:

One issue of particular concern is the situation of the Roma. The Commission has repeatedly highlighted the difficult conditions faced by Roma communities in Member States, candidate countries and acceding countries. Substantial amounts of financial assistance have been provided from the EU budget, including over $€ 100$ million through the PHARE programme for projects specifically targeting Roma. However, the Roma continue to experience particularly severe forms of exclusion and discrimination in education, employment, housing, healthcare and other areas. ${ }^{29}$

The 2005 framework strategy is the source of several additional groups and initiatives subsequently established by the EU. First, a highlevel advisory group on the social and labour market integration of disadvantaged ethnic minorities was established and had its first meeting in February 2006. Headed by the former President of the German Parliament, its members come from business, local government, civil society,

\footnotetext{
27 European Parliament, 'Resolution on the situation of the Roma in the European Union' P6_TA(2005)0151 <http://www.europarl.europa.eu/sides/getDoc.do?pubRef=-//EP// TEXT+TA+P6-TA-2005-0151+0+DOC+XML+V0//EN> accessed 1 November 2006.

28 European Commission, 'Communication from the Commission to the Council, the European Parliament, the European Economic and Social Committee and the Committee of the Regions: Non-discrimination and equal opportunities for all - A framework strategy' (Communication) COM (2005) 224 final, 1 June 2005, 3-4 <http://ec.europa.eu/employment_social/fundamental_rights/pdf/ey07/com07_en.pdf> accessed 18 March 2007.

29 Ibid 10.
} 
academia, and the media. Commissioner Špidla opened the first meeting of this group, emphasising the importance of social cohesion in a more ethnically diverse EU post-enlargement. He also noted that 'the difficult situation faced by the Roma throughout Europe - in terms of employment, education, housing and other areas' is an issue 'of particular concern'. The group will promote best practices in the integration of disadvantaged ethnic groups in the labour markets and will provide the EU with its recommendations by the end of 2007. ${ }^{30}$

Also, the Framework Strategy designated 2007 the 'European Year of Equal Opportunities for All' with the purpose of increasing people's awareness of their rights and promoting equal opportunities. The Year was launched with the recognition that 'despite widespread legal protection, discrimination continues to exist and further efforts are needed to ensure that the right not to be discriminated against is implemented effectively in an enlarged European Union'. ${ }^{31}$ An annual, high level 'Equality Summit' was also launched in 2007. Most recently, on 1 March 2007 a new European Union Agency for Fundamental Rights (FRA) came into being, the successor agency to the European Monitoring Centre on Racism and Xenophobia (EUMC). Its role is to assist the EU and its Member States in their implementation of EU law on fundamental rights issues by providing information, advice, and other support, including the publication of an annual report on fundamental rights in the EU. Monitoring racism and xenophobia remains the main focus of the institution..$^{32}$ Just a month after its inauguration, the FRA had already issued a press release calling for more action to address the situation of the Roma. ${ }^{33}$ Thus, overall it can not be denied that the EU has moved forward the issue of anti-discrimination since 2000, continued to increase its attention to the issue since enlargement, and has continued to include the Roma as a target of its attention.

\section{The Impact of EU Anti-Discrimination Policy and Initiatives}

Given the significant strengthening of EU legislation regarding discrimination, the various institutions and bodies established to address

\footnotetext{
30 European Commission, 'Expert group to promote inclusion of ethnic minorities in the EU' (13 February 2006) <http://ec.europa.eu/employment_social/emplweb/news/news_ en.cfm?id=126>.

31 European Commission, 'Special Eurobarometer 263: Discrimination in the European Union' (January 2007) <http://ec.europa.eu/public_opinion/archives/ebs/ebs_263_sum_ en.pdf> accessed 18 March 2007.

32 See FRA web page <http://www.eumc.europa.eu/eumc/index.php> accessed 7 April 2007.

33 European Union Agency for Fundamental Rights, 'Situation of Roma in Europe Demands More Rigorous Action' (Press Release, 4 April 2007) <http://fra.europa.eu/eumc/ index.php?fuseaction=content.dsp_cat_content $\&$ catid $=45 \mathrm{ffbdd} 45872$ a $\&$ contentid $=461 \mathrm{f} 626$ 535007> accessed 7 April 2007.
} 
and monitor discrimination, and the specific attention paid by the EU to the special situation of the Roma, the next important question is what has been the actual impact. The following sections consider the impact in terms of changes in EU Member States' policies, changes in the situation of the Roma themselves, and changes in the attitudes of the general population.

\section{Implementation of the Race Directive and Impact on the Roma}

In terms of adopting domestic legislation to comply with the EU's anti-discrimination policy, it seems clear that the Racial Equality Directive has had an impact, but this impact has been gradual and is not entirely complete. The deadline for fully transposing the Racial Equality Directive into national law was 19 July 2003 for the original $15 \mathrm{EU}$ Member States, while the new Member States had until their entry date to comply. Some countries met this deadline; others did not.

Before enlargement, assessments of the implementation of the Race Directive were mixed, with some countries fully complying with the Directive, others partially complying, and some not complying at all. About a year before enlargement, it was reported that more efforts were needed but that most countries were moving in the appropriate direction. For example, a September 2003 European Commission report on the status of implementation of legislation in EU candidate countries in accordance with the two Directives found that (as of mid-2003) 'no candidate country has yet fully implemented the requirements of either Directive,' but most states were at least in the process of doing so (and some were even considering stronger legislation than necessary). ${ }^{34}$ Even though it was almost a year before the deadline for most (and longer for some), more than half of the countries (Romania, Slovakia, Latvia, Slovenia, Lithuania, and Malta) had adopted legislation to implement the Directives, although none were fully compliant. Except for Turkey, all of the other candidate states had begun to discuss the issue and three of them (Bulgaria, Estonia, and Poland) had submitted draft legislation to Parliament. ${ }^{35}$

The Roma were specifically addressed frequently in the national assessment reports in 2003 in terms of being a community facing severe disadvantage, including discrimination in education, accessing services, and 'very poor accommodation conditions'. ${ }^{36}$ The report on the Czech Republic found its treatment and protection of minorities, especially of the

34 European Commission (Office for Official Publications of the European Communities), 'Equality, Diversity and Enlargement: Report on measures to combat discrimination in acceding and candidate countries' (September 2003) 8 <http://ec.europa.eu/employment_ social/fundamental_rights/pdf/pubst/equaldivenlarge_en.pdf> accessed 18 March 2007.

35 Ibid 10-12.

36 Ibid 18. 
Roma, to be 'problematic' and noted that 'Roma continue to face discrimination in all aspects of society'. This included placing Roma in special schools for the mentally disabled, employment discrimination, segregated housing, and racist violence. The country's draft anti-discrimination law had not yet been submitted to Parliament. ${ }^{37}$ Interestingly, Romania (which did not expect to join the EU before 2007) appeared to be ahead of the other countries on most issues according to this assessment and was explicitly stated as being the furthest along in terms of transposition. For example, Romania (in mid-2003) was the only country that clearly had legislation prohibiting discrimination in housing, the only country with a special body for hearing discrimination cases (which had already heard complaints and issued decisions), and the country that had gone furthest in terms of positive action (with quotas for universities to admit Roma students). ${ }^{38} \mathrm{~A}$ number of other countries had also taken positive actions to promote equal opportunities for the Roma, including the Czech Republic, Hungary, Slovakia and Slovenia. ${ }^{39}$

The 2003 report concludes that 'although none of the candidate countries has fully transposed the Racial Equality and Employment Equality Directives, there is ample evidence that the Directives are shaping the development of anti-discrimination law in these states'. ${ }^{40}$ It should be noted that on some issues, it was a bit too soon to make an evaluation. As for example the report indicates, the effectiveness of sanctions could not be accurately addressed in many cases due to the minimal number of court cases on discrimination. ${ }^{41}$ Nonetheless, in terms of legislation, it is clear that progress had been made even before enlargement and that EU policy was the impetus.

In terms of the actual improvement of the situation of the Roma, assessments by both pro-Roma NGOs and EU officials prior to enlargement generally noted little change. For example, at the April 2004 'Roma in an enlarged European Union' conference, Odile Quintin, Director-General of the European Commission's DG for Employment and Social Affairs, indicated that despite legislative reforms and EU financial support, the social exclusion and discrimination of the Roma 'remain often extreme' and 'Roma communities continue to face serious problems' in both old and new Member States. ${ }^{42}$ The European Roma Information Office (ERIO), 
in its response to the Green Paper in mid-2004, states that marked discrimination and social exclusion of the Roma remain, and despite the large amount of money spent on improving their situation, 'the situation of Roma has not changed much over the recent years and in many cases has even deteriorated as a result of economic crisis and the recrudescence of nationalism'. ${ }^{43}$ Overall, it states that, although EU actions had a positive impact on the Roma, 'the impact of EU legislation [on the Roma] is minimal'. ${ }^{44}$ On the ground interviews with Roma NGOs in the Czech Republic and Romania prior to enlargement revealed that some felt there had been improvements, but they were still fairly small.

On the other hand, one of the important impacts of the Anti-Discrimination Directives in regards to the Roma at this time is that it brought much greater attention to the discrimination against the Roma in the old EU Member States. The apparent EU double-standard - criticising the Roma situation in candidate countries but ignoring it in Member States - was a criticism that NGOs had begun to take up in the years leading up to enlargement. With the new legislation, old EU Member States came under more specific scrutiny, especially through various monitoring reports, and were also compelled to take specific actions. If a Member State fails to implement, fully comply with, or communicate transposition of a Directive, it may ultimately be brought to the European Court of Justice (which may ultimately impose a penalty payment upon it). In regards to the Race Directive, as of mid-2004, the Commission had already referred five Member States (Austria, Finland, Germany, Greece and Luxembourg) to the European Court of Justice on these grounds. ${ }^{45}$ While the case was dropped against Greece after it adopted legislation, in 2005 the ECJ ruled against Finland, Luxembourg, Germany, and Austria for failing to fully transpose the Race Directive (including in some cases not having yet adopted any legislation). ${ }^{46}$

However, a Commission report in 2005 found that many EU Member States had made 'significant progress' over the previous year in implementing the two Discrimination Directives, including many of the EU 15. In regards to the ten new Member States, a lot of new legislation was apparently adopted 'in the months leading up to EU enlargement'. ${ }^{47}$ All of

43 ERIO $2<$ http://ec.europa.eu/employment_social/fundamental_rights/pdf/greencon/ erio.pdf> accessed 19 March 2007.

44 Ibid 3, 4.

45 European Commission, 'Commission goes to the European Court of Justice to enforce EU anti-discrimination law' IP (2004) 947, 19 July 2004 <http://ec.europa.eu/employment_social/fundamental_rights/pdf/arct/prinfringe947_en.pdf $>$.

46 European Commission (n 18) 12; ECJ rulings available at <http://ec.europa.eu/employment_social/fundamental_rights/legis/lginfringe_en.htm>.

47 European Commission (n 18) 9. 
the new Member States that joined in 2004 had by the end of that year notified the Commission of the transposition of the Directive except for the Czech Republic. ${ }^{48}$ Again, it is noted in 2005 that 'despite this progress, discrimination continues to exist and more needs to be done to ensure that the legal framework is properly implemented and enforced'. ${ }^{49}$ In its communication to the Council and Parliament in June 2005, the European Commission concludes that there have been 'significant changes in national law across the EU as a direct result of EC anti-discrimination legislation' but with some important gaps in some countries, including the absence of effective Equality Bodies and insufficient effort to inform people of their anti-discrimination rights. ${ }^{50}$

As of early 2006, the European Network of non-discrimination legal experts had a fairly positive assessment of the 25 Member States' transposition of the Anti-Discrimination Directives. Seventeen of the 25 had generally transposed the two Directives, although some countries required further action. ${ }^{51}$ For example, Germany had adopted legislation in 2006 that is 'in many respects a satisfactory implementation of the directives and in some respects even goes beyond what is demanded by Community law,' but has some 'severe shortcomings' that would need to be corrected. ${ }^{52}$ Four Member States (Czech Republic, Poland, Malta, Estonia) still needed to transpose the race directive in all fields outside of employment. ${ }^{53}$ Finally, the Commission's December 2006 report to the Council and the Parliament concluded that all 25 Member States had transposed the Directive into national law except Luxembourg, where draft legislation was in the process of being adopted. ${ }^{54}$ When Romania and Bulgaria joined the EU in January 2007, they had both already transposed the Directive as well. Thus, overall, significant though sometimes slow progress has been achieved on the legislative front, perhaps a necessary first step towards further achievements on the actual situation of the Roma.

\footnotetext{
48 Ibid 12.

49 Ibid 5.

50 European Commission (n 28) 4.

51 Mark Bell, Isabelle Chopin and Fiona Palmer, Developing Anti-Discrimination Law in Europe: The 25 EU Member States Compared (The European Network of Legal Experts in the Non-Discrimination Field, Utrecht 2006) 12.

52 The European Network of Legal Experts in the Non-Discrimination Field, 'News from the EU Member States' (2006) 4 European Anti-Discrimination Law Review 60.

53 Bell et al (n 51) 8-9.

54 European Commission, 'Report from the Commission to the Council and the European Parliament: The application of Directive 2000/43/EC of 29 June 2000 implementing the principle of equal treatment between persons irrespective of racial or ethnic origin' COM (2006) 643 final/2, 15 December 2006, 4 <http://ec.europa.eu/employment_social/fundamental_rights/pdf/legisln/racerepco_en.pdf> accessed 21 March 2007. It should be noted, however, that the Czech Republic has not actually transposed the Directive yet.
} 


\section{Discrimination Complaints and Court Cases}

Legal cases brought on grounds of racial discrimination both at the national and international level have also shown mixed results but movement in a positive direction. According to Roma rights activists, there have been important successes as well as significant disappointments in this area. It should not be discounted, however, that the increased attention to and legislation on ethnic discrimination on the EU level, and increased attention in particular to discrimination against the Roma, has made it more likely for these cases to succeed. With the full transposition of the Race Directives, new cases will also become possible in the future. At the same time, it must be recognised that change through litigation, while perhaps critical, is a very slow process, especially at the international level. It is perhaps even slower in the case of the Roma, in which the majority of violations against individuals will probably go unchallenged, and most individuals must rely on pro-Roma NGOs to take up their cases. ${ }^{55}$

Regarding complaints brought to either courts or equality bodies under the new Race Directive, the Roma were the group that submitted the most complaints in most of the ten 2004 new Member States. On the one hand, this can be seen as an indication of the extent of discrimination against the Roma; a Commission report considers it an indication that 'the Directive is being successfully used to challenge discrimination against that group'. ${ }^{56}$ In terms of judicial decisions, one notable example of success at the national level is the Prague Airport case in the UK. In December 2004, the UK House of Lords ruled that the UK government's setting up of passport checks in the Prague airport in 2001 to screen passengers headed to the UK - and ostensibly to prevent Roma from travelling to the UK where they might seek asylum - was 'inherently and systematically discriminatory' against Czech Roma on racial grounds. The practice was one widely criticised by Roma and pro-Roma NGOs when it occurred, ${ }^{57}$ and according to the ERRC this legal decision is among the most important ever anywhere in terms of condemning racial discrimination in the area of border regulation'. ${ }^{58}$ A number of positive court decisions regarding the Roma can also be found in new Member States following their adoption of anti-discrimination legislation. For example, according to the ERRC (which brought many of the cases), over a period of two and a half years following the entering into force of Bulgaria's Pro-

\footnotetext{
55 Galina Kostadinova, 'Substantive Equality, Positive Action and Roma Rights in the European Union' (Minority Rights Group International, 2006) 2.

56 European Commission (n 54) 4.

57 Ram (n 2) 48.

58 ERRC web page <http://www.errc.org/About_index.php> accessed 31 Oct. 2006.
} 
tection against Discrimination Act in January 2004, Bulgarian courts had already ruled in about 27 discrimination cases, 16 of them with favourable rulings. These included a number of 'landmark' judgments regarding the Roma. ${ }^{59}$

In racial discrimination cases brought to the European Court of $\mathrm{Hu}-$ man Rights, activists have noted a disappointing history, but some positive recent movement. In terms of the historical record, as Claude Cahn, Programmes Director at the ERRC states the Court had never found a violation of Article $14^{60}$ of the European Convention on Human Rights on the grounds of racial discrimination, and until early 2004 there were only two positive rulings on racial discrimination at all. ${ }^{61} \mathrm{He}$ cites a judge's dissenting opinion in a 2002 case regarding the Roma that clearly emphasises this point:

Frequently and regularly the Court acknowledges the members of vulnerable minorities are deprived of life or subjected to appalling treatment in violation of Article 3; but not once has the court found that this happens to be linked to their ethnicity. Kurds, coloureds, Muslims, Roma and others are again killed, tortured or maimed, but the Court is not persuaded that their race, colour, nationality or place of origin has anything to do with it. ${ }^{62}$

In Cahn's opinion, however, the situation has begun to improve: 'In the past two years, a shift appears to be taking place at the Court, with the result that greater credence is now being given to the problem of racial discrimination, and some states have been held to account in recent decisions involving racial discrimination'. ${ }^{63}$

Some notable cases regarding the Roma, all launched years ago in national courts have finally recently seen results at the international level, some quite positive from the point of view of activists. For example, in February 2004, in the case Nachova $v$ Bulgaria, the Court ruled in a

59 ERRC, 'Justice for Romani Victims of Racial Discrimination in Bulgaria' (World Conference Against Racism (WCAR) listserv, 10 June 2006) <http://www.hrea.org/lists/ wcar/markup/msg00269.html>; ERRC, 'First Five Roma Rights Victories under New Bulgarian Equality Law' (Press Release, 30 September 2004) <http://www.errc.org/cikk. php?cikk=2022> accessed 25 May 2007.

60 Article 14 ECHR states: 'The enjoyment of the rights and freedoms set forth in this Convention shall be secured without discrimination on any ground such as sex, race, colour, language, religion, political or other opinion, national or social origin, association with a national minority, property, birth or other status.'

${ }_{61}$ Claude Cahn, 'The Elephant in the Room: On Not Tackling Systemic Racial Discrimination at the European Court of Human Rights' (2006) 4 European Anti-Discrimination Law Review 13.

62 Anguelova v Bulgaria (App no 38361/97) (13 June 2002), cited in Cahn (n 61) 13.

63 Cahn (n 61) 13. 
unanimous judgment against Bulgaria for the deaths of two Romani men and for not effectively investigating the incident. As the ERRC and the judge's concurring opinion emphasise, this was the first time the Court had ever found a violation of Article 14 on the basis of racial discrimination taken together with Article 2 (right to life). ${ }^{64}$ Another important case involves an anti-Roma pogrom in the Romanian village of Hadareni that resulted in the death of three Romani men and the burning of numerous Romani houses. The Court ruled in 2005 that Romania had violated several Articles of the European Convention on Human Rights. ${ }^{65}$ On the other hand, in a Court ruling in 2006 on a much-publicised case of racial segregation of the Roma in the education system in the Czech Republic (which began in the national courts in 1999), the Court did not find the actions to be discriminatory or the result of racial prejudice. The Grand Chamber subsequently agreed to review the ruling, and its judgment is expected later this year. ${ }^{66}$ The ERRC has called this case "one of the most important cases ever to come before the Court' in that it raises major issues regarding the prohibition of discrimination under Article $14 .{ }^{67}$

While the Strasbourg Court has not had favourable rulings for the Roma in every case (nor should we expect it to), the apparent progress should not be overlooked. Of the sixteen cases with Roma defendants in which there were judgments since February 2001, the Strasbourg Court found some violations in all except two (the aforementioned Czech case and a case against the Netherlands). These included violations by the UK, Belgium, Hungary, Romania, Bulgaria, Macedonia, Greece, and most recently (May 2007) Croatia. In half of these sixteen cases, a violation of Article 14 was considered by the Court and half of these judgments (all since mid-2005) found such a violation. Recently (April 2007), two cases against Romania were even struck out by the Court when the Government of Romania pre-emptively acknowledged responsibility for violating several articles of the European Convention on Human Rights, including Article $14 .{ }^{68}$ Overall, the positive judgments that have begun to emerge

\footnotetext{
64 Branimir Pleše, 'The Strasbourg Court Finally Redresses Racial Discrimination' (2004) 1 Roma Rights Quarterly <http://www.errc.org/cikk.php?cikk=1851> accessed 24 March 2007; Nachova and Others $v$ Bulgaria (App nos 43577/98 and 43579/98) (26 February 2004). On the other hand, when this case was taken to the Grand Chamber, it ruled that a violation of Art 14 together with Art 2 could be found only in its procedural aspect, not in its substantive aspect; Nachova and Others $v$ Bulgaria (App nos 43577/98 and 43579/98) (6 July 2005).

65 Cahn (n 61) 15.

66 Ibid 20.

67 ERRC, 'Europe's Highest Court Hears Oral Arguments in Landmark Segregation Case' (17 January 2007) <www.errc.org/cikk.php?cikk=2715> accessed 24 March 2007.

68 ERRC, 'Romanian Government Acknowledges Responsibility for Anti-Romani Pogroms' (27 April 2007) <http://www.errc.org/Popup_index.php?type=nyomtat\&id=2748> accessed 3 May 2007.
} 
in national and international courts regarding discrimination against the Roma are a significant development. It will, however, take time before the impact of these and future cases are felt on the ground in terms of reduced discrimination.

While EU anti-discrimination legislation and the domestic policy changes and institutions, reports, public attention, and court cases it has engendered are significant, few would argue that discriminatory practices against the Roma do not remain widespread. And as the EU Network of Independent Experts on Fundamental Rights makes clear in its 2005 Thematic Comment on the protection of minorities in the EU, problems remain throughout both the old and new Member States, particularly (but not only) in segregation in education and housing. ${ }^{69}$ Legislation will likely continue to bring some improvements in the actual situation of the Roma, but at a relatively slow pace. It seems reasonable to argue, as the EU Network, the European Roma Information Office, the European Roma Rights Centre, Minority Rights Group, and others have done, that additional steps - including some type of affirmative action - may be required to adequately address the situation of the Roma. As the EU Network stated in its first annual report in 2003, 'no minority is more under threat today in Europe than the Roma people [. . .] The prohibition of discriminatory acts does not suffice, since a long history of exclusion covering all areas of economic, political and social life needs to be overcome'.$^{70}$ Its call for additional actions regarding the Roma has been repeated in its subsequent reports, including a proposal from 2004 for a Roma Directive as 'the most important contribution which the European Community could make to the protection of minorities, within the framework of its existing powers'. ${ }^{71}$ In its latest report in 2005, the Network repeated this call on the basis of continued widespread discrimination against the Roma, including 'widespread segregation' in education, housing, employment, and access to health care. ${ }^{72}$ This proposal has been strongly supported by the ERRC and the ERIO. Besides calls for a Directive specifically aimed at Roma integration, there have also been proposals for the Commission

69 EU Network of Independent Experts on Fundamental Rights, 'Thematic Comment No 3: The Protection of Minorities in the European Union' (25 April 2005) <http://ec.europa.eu/ justic_home/cfr_cdf/doc/thematic_comments_2005_en.pdf> accessed 12 March 2007.

70 EU Network of Independent Experts on Fundamental Rights, 'Report on the Situation of Fundamental Rights in the European Union and its Member States in 2002' $176<$ http:// ec.europa.eu/justice_home/cfr_cdf/doc/rapport_2002_en.pdf> accessed 12 March 2007.

71 EU Network of Independent Experts on Fundamental Rights, 'Report on the Situation of Fundamental Rights in the European Union in 2003' $103<$ http://ec.europa.eu/justice_home/cfr_cdf/doc/report_eu_2003_en.pdf> accessed 12 March 2007.

72 EU Network of Independent Experts on Fundamental Rights, 'Report on the Situation of Fundamental Rights in the European Union and its Member States in 2005: Conclusions and Recommendations' 186-7 <http://ec.europa.eu/justice_home/cfr_cdf/doc/report_eu_ 2005_en.pdf> accessed 12 March 2007. 
to establish a Roma coordination office and an Action Program for the Roma. ${ }^{73}$

\section{Changes in Attitudes of the General Population}

It is frequently acknowledged by EU institutions and widely agreed by others that legislative reform without changes in racist attitudes among the general population will not be sufficient to combat discrimination. Interviews with Roma organisations in the Czech Republic, for example, also emphasised this point. Racist attitudes towards the Roma in many countries are clear even to a casual observer, and addressing this problem must go hand in hand with legislative changes. A number of surveys have been conducted in recent years to discern the extent of discrimination in EU countries and whether or not it has diminished. Unfortunately, these surveys are not directly comparable, and also are influenced by the fact that greater awareness of and attention to discrimination (in the media and elsewhere) have made people more aware of the problem and therefore more likely to report that it exists. Nonetheless, it is fairly safe to conclude from these surveys that ethnic discrimination remains widespread in the EU and people perceive this as a problem that should be addressed.

Prior to enlargement (in 2002), a special Eurobarometer survey on discrimination was carried out in the 15 EU Member States under the EU-wide action programme against discrimination. For the purposes of the survey, discrimination was defined as 'treating differently, negatively and adversely people on grounds of their racial or ethnic origin, religion or beliefs, disability, age and sexual orientation'. ${ }^{74}$ While few survey respondents (which only included EU citizens) reported experiencing discrimination themselves, a fairly large number (22\%) claimed to have witnessed discrimination on the basis of race or ethnic origin (the ground cited most often for 'witnessed discrimination'). ${ }^{75}$ Moreover, $62 \%$ thought a person of a different ethnic origin would have less chance of 'getting a job, training or promotion'. ${ }^{76}$ Moreover, more than three-quarters of respondents (77\%) in the EU 25 see 'being a Roma' as a disadvantage in their countries. ${ }^{77}$

\footnotetext{
73 ERIO (n 43) 2, 4.

74 European Commission (DG Employment \& Social Affairs), 'Eurobarometer 57: Discrimination in Europe' (May 2003) 4 (surveys conducted February - April 2002) <http:// ec.europa.eu/employment_social/fundamental_rights/pdf/aneval/eurobarometer57_ en.pdf> accessed 15 March 2007.

75 Ibid 9.

76 Ibid 10.

77 Ibid 5.
} 
According to a World Bank qualitative survey based on focus groups in Bulgaria, Croatia, Czech Republic, Hungary, Macedonia, Montenegro, Romania, Serbia, and Slovakia in June 2005, 'virtually all [non-Roma] respondents reported negative associations toward the Roma as a whole,' and moreover they were convinced that their attitudes were based on the characteristics and behaviour of the Roma, not on their own racial prejudices. ${ }^{78}$ This is despite the fact that the respondents in Hungary, Romania, the Czech Republic, and Bulgaria also generally considered their citizens to be 'highly tolerant of minorities'. ${ }^{79}$ There was no indication that the younger generation had necessarily cast off intolerant attitudes. In some countries, the younger generation expressed more tolerant attitudes (for example, Slovakia) while in others the opposite was true (e.g. Hungary). ${ }^{80}$ There was also no indication that discrimination was no longer a concern. 'All Roma respondents reported that social discrimination is a routine part of their day-to-day lives,' although there were differences of opinion on whether or not tolerance towards Roma and other minorities had increased or decreased. ${ }^{81}$ Nonetheless, there was generally strong support for the idea of 'equal opportunity for all,' suggesting this might be a message on which further action could be built. ${ }^{82}$

In mid-2006, a second special Eurobarometer survey on discrimination and inequality was carried out in the 25 EU Member States plus Romania and Bulgaria. Of the six prohibited forms of discrimination examined in the survey (discrimination on the basis of sex, ethnic origin, religion or beliefs, age, disability, and sexual orientation), ethnic discrimination was perceived as being the most widespread (with 64\% of people in the EU25 believing discrimination on the basis of ethnicity is widespread). ${ }^{83}$ This view varied significantly among countries. For example, the number was 39\% in Romania, $48 \%$ in Germany, and 51\% in the Czech Republic. ${ }^{84}$ In terms of their own views on other races, however, a

78 World Bank, 'Current Attitudes Toward the Roma in Central Europe: A Report of Research with Non-Roma and Roma Respondents' (September 2005) $10<$ http://siteresources.worldbank.org/INTROMA/Resources/RomaQualitativeSurveyExecSummary.doc> accessed 15 March 2007; see also individual country reports at <http://web.worldbank.org/WBSITE/EXTERNAL/COUNTRIES/ECAEXT/EXTROMA/ 0,,contentMDK:20749979 pagePK:64168445 piPK:64168309 theSitePK:615987,00.html>.

79 Ibid 9.

80 Ibid 11-12.

81 Ibid 3.

82 Ibid 5.

83 European Commission, 'Special Eurobarometer 263: Discrimination in the European Union - Summary' (2007) 4, 7 (surveys conducted June - July 2006) <http://ec.europa. eu/public_opinion/archives/ebs/ebs_263_sum_en.pdf> accessed 15 March 2007.

84 Ibid 7. The highest percentages of people who believed that ethnic discrimination was widespread in their country were in Sweden (85\%), the Netherlands (83\%), France (80\%), Denmark (79\%), Belgium (78\%) and Italy (77\%). 
positive finding was that $65 \%$ of the EU25 believe that people of different ethnicities in their countries enrich their country's culture. ${ }^{85}$

In terms of changes in discrimination, $49 \%$ of people in the EU25 responded in the 2006 survey that discrimination on the basis of ethnic origin in their country is now more common than five years ago (while $42 \%$ believe it is less widespread). ${ }^{86}$ However, this number is lower in most countries of Central and Eastern Europe, perhaps because of the increased attention to discrimination in their countries in recent years. For example, in Romania only $29 \%$ believe discrimination is more common than five years ago, and in the Czech Republic 34\%. ${ }^{87}$ The majority of people in the EU support further action being taken to combat discrimination, although it is not agreed on what level this action should be taken. In the EU25, 51\% of respondents think that not enough effort is being made in their country to combat discrimination, while $45 \%$ think enough effort is being made. ${ }^{88}$ Among various institutions and actors, only $10 \%$ of the EU 25 according to this survey think the EU has an important role to play in combating discrimination (with the highest percentage (42\%), believing schools \& universities have an important role. ${ }^{89}$ On the other hand, a different poll conducted around the same time found that a large majority (73\%) of the $25 \mathrm{EU}$ Member States (and a majority in each country) believe more decision-making should take place at the European level to promote and protect 'fundamental rights'. ${ }^{90}$ The Commission's 2006 survey also reveals that many people remain unaware of the legal prohibitions in their country on discrimination, as well as of their own legal rights. ${ }^{91}$ Although there are difficulties in evaluating these survey results, the data clearly reinforce other assessments that discrimination remains prevalent across the EU, especially on ethnic grounds and including against the Roma. A majority of people in the EU also seem to agree that this situation is a problem and that, despite the efforts already made by their countries, it should be further addressed at some level.

\footnotetext{
85 Ibid 9.

86 European Commission, 'Special Eurobarometer 263: Discrimination in the European Union' (2007) (surveys conducted June - July 2006) $10<$ http://ec.europa.eu/public_opinion/archives/ebs/ebs_263_en.pdf> accessed 15 March 2007.

87 Ibid 38.

88 European Commission (n 83) 21.

89 Ibid 22.

90 The number was 70\% or more in all of the Central and East European countries of the EU 25, except for the Baltics. It was as high as $80 \%$ in the Czech Republic. European Commission, 'Special Eurobarometer 266: The Role of the European Union in Justice, Freedom, and Security policy areas' (2007) 10 (surveys conducted June - July 2006) <http://www. ec.europa.eu/public_opinion/archives/ebs/ebs_266_en.pdf> accessed 15 March 2007.

91 European Commission (n 83) 24-25.
} 


\section{Conclusion}

In the period just leading up to and following the EU's enlargements to Central and Eastern Europe in 2004 and 2007, there have been changes in the rights of the Roma in Europe, significantly facilitated by the adoption of the EU's Anti-Discrimination Policy. However, one might summarise the situation as significantly more action and attention at both the EU and Member State level, but as yet minimal change in the actual situation of the Roma. One can not deny that there have been more EU institutions and advisory bodies paying attention to the issue (some newly created); continued monitoring and numerous reports on the situation both by NGOs and by (or directly for) EU institutions; more attention to anti-Roma discrimination in the original 15 EU Member States (in addition to the continuing attention to the situation in the new Member States); and discussion of possible further EU policies and initiatives to strengthen the attention and reduce the problems. On the national level, new legislation has been adopted and institutions created in the majority of EU Member States (new and old), although it will still require some time to see how well these laws and institutions function in practice. Reports indicate no discernible change in discrimination itself, although possibly a move towards greater tolerance and acceptance of the principle of equality. The Race Equality Directive and the EU's anti-discrimination agenda more broadly have given activists new tools to use in their rhetoric and their court cases. In prosecuting individuals for discriminatory practices, success appears to be growing, although remains mixed. Finally, there is slightly more activism at the EU level, thanks in part to Roma in the European Parliament, the recently established European Roma Information Office in Brussels, and a fairly coordinated message among international NGOs lobbying for Roma rights.

So far, the changes in the actual situation of the majority of Roma appear to be relatively small, (although it should not be discounted that there has been a major impact on the development of a Roma elite). Certainly the rhetoric of Roma rights activists has changed little since EU enlargement. As for example the European Roma Rights Centre stated this April on International Roma Day, 'across Europe, the fundamental rights of Roma are still being violated on a regular basis. Repetitious cases of racist violence and hate speech targeting Roma are reported frequently. Roma are also subject to discrimination in accessing employment, education, health care, and public and social services'. ${ }^{92}$ As Rudko Kawczynski, head of the European Roma and Travellers Forum recently stated on the occasion of the $50^{\text {th }}$ Anniversary of the Treaty of Rome, 'we are today wit-

92 ERRC, 'International Roma Day: A Day to Raise Awareness of the Human Rights Problems Experienced by Roma' (MINELRES listserv, 11 April 2007). 
nessing the absurd situation where people have many rights on paper, but no means to actually achieve them'. In his view, the EU has certainly contributed to improving the conditions of the Roma, but full equality is far from being achieved. ${ }^{93}$ The European Union Agency for Fundamental Rights' Interim Director drew much the same conclusion in a statement just last month:

The discrimination and disadvantage faced by Roma and Travellers in Europe is a well-documented fact. Solutions have been outlined in action plans and numerous strategies. What we need now is more action on the ground, the rigorous implementation of adequatelyresourced policies, and specific measures that tackle deep-rooted discrimination and negative stereotypes. ${ }^{94}$

Overall, the EU has played a crucial role in advancing the agenda of non-discrimination and bringing attention to the specific problems faced by the Roma in this regard. It has not dropped the issue from its concerns following enlargement, but has arguably strengthened it. Yet, it remains clear that the situation of the Roma will provide ample grounds for Roma activists to continue their work in Europe for many years to come.

\footnotetext{
93 European Roma and Travellers Forum, 'Europe celebrates its $50^{\text {th }}$ birthday: For Roma no time to party' (Press Release, 25 March 2007) (MINELRES listserv, 26 March 2007).

94 European Union Agency for Fundamental Rights, 'Situation of Roma in Europe Demands More Rigorous Action' (Press Release, 4 April 2007) <http://fra.europa.eu/eumc/ index.php?fuseaction=content.dsp_cat_content $\&$ catid $=45 \mathrm{ffbdd} 45872$ a $\&$ contentid $=461 \mathrm{f} 626$ 535007> accessed 8 April 2007.
} 